\title{
Factors affecting on the leaving job and reentry for the Japanese dental hygienist
}

\section{Yoshiaki Nomura ( $\square$ nomura-y@tsurumi-u.ac.jp)}

Tsurumi University https://orcid.org/0000-0002-0814-0572

\section{Ayako Okada}

Tsurumi University School of Dental Medicine

\section{Yuko Yamamoto}

Tsurumi University School of Dental Medicine

\section{Erika Kakuta}

Tsurumi University School of Dental Medicine

\section{Hiroshi Tomonari}

Tsurumi University School of Dental Medicine

\section{Noriyasu Hosoya}

Tsurumi University School of Dental Medicine

\section{Nobuhiro Hanada}

Tsurumi University School of Dental Medicine

\section{Naomi Yoshida}

Japanese Dental Hygienists' Association

\section{Noriko Takei}

Japanese Dental Hygienists' Association

\section{Research article}

Keywords: Dental Hygienist, leaving job, reentry, working environment

Posted Date: July 30th, 2019

DOI: https://doi.org/10.21203/rs.2.12115/v1

License: (-) This work is licensed under a Creative Commons Attribution 4.0 International License. Read Full License 


\section{Abstract}

Background Working dental hygienists is not sufficient. About $40 \%$ licensed dental hygienist are leaving their professional jobs. Re-entry of leaving dental hygienist is expected to compensate the unbalance of demand and supply. The purpose of this study was to identify the obstacles for re-entry of leaving dental hygienists and propose the countermeasures for supporting re-entry Methods The Japan Dental Hygienists Association has been conducted survey of the Employment Status of Japanese dental hygienist every 5 years since 1981. Questionnaires were distributed for all members of the Japan Dental Hygienists Association. Among the 94 items, following eight specific items were used for analysis: 1 . The reason of leaving the job. 2. How long have you been leaving the job? 3 . Willingness to reentry. 4. How do you find your work for re-entry? 5 . Is there any obstacle for the reentry? 6 . What is your obstacle for reentry? 7. Do you need lecture course for reentry? 8. What kind of lecture course contents do you want to attend? Results Questioners were distributed for 16,113 members of Appeases Dental hygienist Association, and 8,780 were responded (collection rate: 54.5\%). By log-linear analysis, for the reason of leaving the job, dissatisfaction with work content and marriage were significant in age groups $\leq 29$ and 30-39. Child birth / child rearing were significant in age groups of $\leq 29,30-39$ and 40-49. Payment were significant in 30-39 and 40-49.Child birth / rearing and working hours were most important impact on the leaving job and obstacle for reentry. In this study, number of dental hygienist who leave the job by child birth / rearing was highest. Conclusion Workplace improvement including flexible working time may be most important factors or the reentry for the dental hygienist with leaving jobs. Social support system is indispensable to improve women's working environment.

\section{Background}

Japan has problems of birthrate decline, population aging and shrinkage of the working population continue to be unabated. The population of Japan in 2018 consisted of $28.0 \%$ by the elderly population (over 65 years old) and $59.7 \%$ by the production age population (15-64 years old) [1]. In order to support this aging society, the Japanese government is advancing counter measures for declining birthrate and reforming of work way. In working way reform, women's reentry to working and reemployment of retired workers by aged are the main stream. For the improvement of women's working environment, child - rearing support system has been improved so that women in child - rearing can easily work. Number of kinder gardens, nursery schools, nursery center, day care center for children and day nursery is not still enough. Number of nursery teacher and childcare worker is not sufficient. Gender barriers are still exited in working environment, especially in wages.

There are approximately 200,000 licensed dental hygienists in Japan, currently working dental hygienist were 123,831[2]. About 40\% licensed dental hygienist are leaving their professional jobs. In Japan's aging society, there is a large need for oral care of the elderly by visit medical and dental treatment. According to the demographics of 2017 of Japan, The number of deaths by pneumonia excluding aspiration pneumonia was 96,807 . It located in the $5^{\text {th }}$ cause of Japanese death. Its crude death of 100 thousand pairs of population was 77.7. The number of deaths by aspiration pneumonia was 35,740 . It located in the $7^{\text {th }}$ cause of Japanese death. The crude death rate of the population 100 thousand pairs was 28.7. Crude death rate of aspiration pneumonia and pneumonia has been boosting [3]. Many studies has been confirmed the effect of professional oral care for the prevention of pneumonia including aspiration [4-7] or influenza [8].

Dental hygienists play a pivotal role in preventing aspiration pneumonia, and despite their expected role, number of dental hygienists are not sufficient. In current situation of one dental hygienist to approximately 1000 people, it is difficult to meet this requirement.

In the Japanese's system of dental service, dental clinics are the main constituent and most of them are private dental clinics. The number of dental clinic was 68,940 at 2017 [9]. Of the 123,831 working dental hygienists, 112,211 (90.6\%) were working in the clinic [2]. The average number of dental hygienists per clinic is 1.6, which includes part-time workers. Working dental hygienists is not sufficient. As welfare programs of private dental clinics are not substantial like civil servants and large corporate workers, dental hygienists are unable to obtain a sufficient vacation due to marriage, childbirth, child rearing, and are now in a state of leaving. As described above, child - rearing support system in Japan is still not enough. Therefore, it is difficult to reinstate in short periods.

In this situation, re-entry of leaving dental hygienist is expected to compensate the unbalance of demand and supply. However, limited information is available for the leaving dental hygienist, because of its information by their local area [10.11] and small samples[12]. From this point of view, the Japanese Dental Hygienist Association has been conducted a survey on working conditions of hygienists on a nationwide scale every five years, including survey items of leaving dental hygienists. However, the results of the survey had been 
reported by descriptive analysis. Causal and statistical inference had not been conducted. The purpose of this study was to identify the obstacles for re-entry of leaving dental hygienists and propose the countermeasures for supporting re-entry by statistical modeling.

\section{Methods}

\section{Survey method}

The Japan Dental Hygienists Association has been conducted survey of the Employment Status of Japanese dental hygienist every 5 years since 1981. Questionnaires were distributed for all members of the Japan Dental Hygienists Association at September 30, 2014 by postage painted mail including stamped addressed envelope for recovery. Survey execution date were set on October 31 . The questionnaires retuned until the November 30 were used for the analysis.

\section{Questionnaire}

The questionnaire used in this study consisted of 94 items concerning demographic factors, employment situation, working contents, willingness to work etc.

For the leaving dental hygienists, seven specific items were applied:

- The reason of leaving the job. Select one.

1. Dissatisfaction with work content, 2. Payment, 3. Trouble in human relations in the workplace, 4. Family Matters, 5. Marriage, 6. Childbirth / child rearing, 7. Nursing care for elderlies of your family, 8. Broke down my health, 9. Interests other than dental job, 10. Retirement, 11. Others

- How long have you been leaving the job?

- Willingness to reentry. Select one.

1. I want to reentry as soon as possible. 2 . I want to reentry if conditions are satisfied. 3 . I do not intend to 4. Univalent.

- How do you find your work for re-entry? Multiple choice.

1. Labor agency 2. Job magazines 3. Introduction from a friend / acquaintance 4. Introduction of dental hygienist school you graduate from 5. Internet 6. Free employment introduction of dental Association and Dental Hygienist Association, 7. Human resource dispatch companies, 8. Other

- Is there any obstacle for the reentry?

1.Yes, 2 No

- What is your obstacle for reentry?

1. Salary, 2. Working hours, 3. My skills, 4. No consultation 5. Aging 6. Others

- Do you need lecture course for reentry?

1.Yes, 2 No

- What kind of lecture course contents do you want to attend?

1.Scaling and route planning, 2.Dental caries prevention and control, 3.Dental health guidance for individuals, 4.Dental health guidance for group, 5. Handling of dental materials, chair side assistant,6.Chair side assistant snap impression, polishing of filling materials, rubber dam etc., 7. Nursing care, 8.Eating / swallowing function training, 9.Muscle function training, 10Counseling techniques, 11. Professional oral care techniques, 12 . Other

The questionnaire in Japanese is available from JAPAN DENTAL HYGIENISTS' ASSOCIATION [13]. 


\section{Statistical analysis}

Descriptive statistics and cross tabulations with age groups were summarized for the questions described above. Chi-square tests were used to find out the statistical significance. In addition, logit model of log-linear analysis were carried out to find out the statistically significant cells. For the contentious variables, after confirmation of their normality, one-way analysis of variance and subsequent Turkey HSD was used for the multiple comparison. Decision analysis was carried out by the classification and regression trees (CART), and the willingness to reentry was used for the objective variable. SPSS Statistics Ver 24.0 (IBM, Tokyo) was used for analysis.

\section{Results}

Questioners were distributed for 16,113 members of Japanese Dental hygienist Association, and 8,780 were responded (collection rate:54.5\%). Table 1 shows the cross tabulation of the specific questionnaire for the leaving dental hygienist against age groups. * indicated the statistically significant cells by log-linear analysis. For the reason of leaving the job, dissatisfaction with work content and marriage were significant in age groups $\leq 29$ and 30-39. Child birth / child rearing were significant in age groups of $\leq 29,30-39$ and 40-49. Payment were significant in 30-39 and 40-49. Trouble in human relations in the workplace was significant only in $\leq 29$. Age groups less than 49 were significantly had willingness of reentry (As soon as possible and If conditions are satisfied).

For the finding jobs, Friend, Dental Association / Dental Hygienist Association, Human resource Dispatch Company were not statistically significant. Most of the lecture course for reentry, age groups $\leq 29$ were significantly wished to attend.

For the contents of lecture course, Scaling and root plaining and chair side assistance were significant for age groups $\leq 29$ to $40-49$. For the obstacle of reentry, salary, working hours, skills were important obstacles for all ages except for the age group of $60 \leq$, however, the skill was not statistically significant in age groups 30-39.

Characteristics of the subject classified by willingness to reentry were shown in Table 2. The subjects with willingness to reentry (As soon as possible and If conditions are satisfied) were younger than subjects without willingness to reentry (I do not intend to and Univalent). Therefore, the subjects who wished reentry were shorter year of working as dental hygienist and shorter year since leaving job.

Child birth / child rearing were statistically significant reason for leaving the job for the subjects with willingness to reentry. Payment were significant only for the subjects answered if conditions are satisfied, however number of the subjects answered for if conditions are satisfied were high. In the subjects not intended to reentry, Interests other than dental job were significant. Working hours and skills were significant obstacles for reentry.

Figure 1 shows the results of decision analysis, if obstacle of reentry was working hours, the reason of job leaving was childbirth / child rearing and year since leaving job was less than 10 year, $94.9 \%$ subjects had willingness to reentry. If obstacle of reentry was not working hours and year of working as dental hygienist was more than 26 years, $75.4 \%$ subjects had not willingness to reentry. Even though obstacle of reentry was not working hours and year of working as dental hygienist was more than 26 years, if the reason of leaving job was family matters, nursing care for elderlies of your family, broke down my health, or retirement, $55.0 \%$ subjects had not willingness to reentry. If obstacle of reentry was not working hours and year of working as dental hygienist was less than 25 years, and year since leaving job was less than 2 year, $64.2 \%$ subjects had willingness to reentry.

\section{Discussion}

The scope of work of dental hygienist differs between the countries. Visiting oral care for the elderlies or medically handy capped patients by dental hygienist without dentist are approved by Japanese insurance system. The ratio of dental hygienists to general dentists in Japan was 1:1. The value of it similar to United States, Canada, Australia, and Germany [14-17]. It was higher than that of Australia, Germany, Italy and Israel $[14,16,17,18]$. However, in accordance with the elderly population in Japan, workforce of dental hygienist is indispensable. Other than that, dental hygienists are a major dental human resource in all countries [19].

Most of the Japanese dental hygienists were employed in private dental office [2].This situation differs between the countries. For example, 47.0\% for United Kingdom [20] and 40.0\% for Hong Kong [21], and 91.5\% for Australia [22]. It should be noticed, when compared the results of this study with other countries. 
In Japan for the education for undergraduate dental hygienist, eight universities have bachelor's degree program and all of the vocational dental hygienist schools became a 3-year diploma program since 2010. The dental hygiene curriculum included oral care and the evaluation of chewing and swallowing function for medically dependent patients [12]. However, post graduate and life-long skill up is necessary. In this point of view, Japan Dental Hygienist Association provide advanced skill up seminars and diploma course on an every prefectures branches basis. The contents of seminars are swallowing function training, muscle function training, paramedic etc. However, the dental hygienist with leaving needed more basic training course (Table 1). Additional planning of the lecture course is necessary for the Japanese Dental Hygienist Association for the reentry.

Child birth / rearing and working hours were most important impact on the leaving job and obstacle for reentry. In this study, number of dental hygienist who leave the job by child birth / rearing was highest. Highest obstacle for the reentry was working hours. In addition, dental highest who had the willingness of reentry leave the job and their obstacle for the reentry was working hours. It may be general trend in worldwide $[20,22,23]$.In addition, hygienists with childcare responsibilities were likely to be working part time workers [20, 23].For the working hours, it was reported that dental hygienists generally satisfied with flexibility in working hours [24, 25]. However, working styles of dental hygienist varied between the countries. In Japan, as described in Introduction, most of dental hygienist employed by private dental clinic, and ratio of dental hygienist/dentist was 1:1. Many private dental office in Japan open until late at night like eight or $9 \mathrm{pm}$. In addition, some of the private dental office open in holidays, many of the private dental office as this style takes the shift working system for the staffs. Under these conditions, many of the dental Japanese hygienist may not satisfied with the working hours and it can be the most important obstacle for the reentry. To overcome these conditions, social support system is indispensable. Japanese government has been tried to improve this women's working environment, however, it is not still enough.

Some of the young dental hygienist leave their job by trouble in human relations in the workplace or dissatisfaction with work content. Japanese students enrolled in the dental hygiene program immediately after high-school graduation without any work experiences. Many of the education for dental hygienist students were carried out by 3-year diploma program at vocational dental hygienist schools. Motivation', 'Expectation' and 'Environment' were significantly higher among the Canadian students over Japanese students[26, 27].Several reports had shown that dental hygienists could obtain high levels of career satisfaction [20,28, 29, 30].Job satisfaction of older dental hygienists was higher than that of younger dental hygienists[20,30]. However, for the young Japanese dental hygienist, the length of education and practical experience may not enough to obtain career satisfaction and job satisfaction. Previous study concluded that continuing professional development is lower priority than workplace improvement for the dental hygienist [31].Therefore, workplace improvement including flexible working time may be most important factors or the reentry for the dental hygienist with leaving jobs.

\section{Conclusion}

Workplace improvement including flexible working time may be most important factors or the reentry for the dental hygienist with leaving jobs. Social support system is indispensable to improve women's working environment.

\section{Declarations}

\section{Ethics approval and consent to participate}

Informed written consent was obtained from all participants. This study was approved by the Ethics Committee of Tsurumi University School of Dental Medicine (approval number:1633) and conducted in accordance with the Declaration of Helsinki.

\section{Consent for publication}

Not applicable.

\section{Funding}

Not applicable.

This survey was carried out by the annual funds of Japan Dental Hygienists Association. 


\section{Availability of data and materials}

The datasets used and/or analyzed during the current study are available from the corresponding author on reasonable request.

\section{Authors' contributions}

YN: performed statistical analysis and prepared the manuscript

AO, YY, EK: performed statistical analysis, data management and prepared the manuscript

HT, NoHo, NoHa: prepared the manuscript and gave scientific advices on the study

NY, NT: planed study design, data management and performed the survey

All authors have read and approved the manuscript, and ensure that this is the case.

\section{Competing interests}

Y.N is an assignment editor of BMC oral health

There are no financial and non-financial competing interests.

\section{Acknowledgements}

Not applicable.

\section{Abbreviations}

Classification and regression trees: CART

\section{Additional file}

Additional file 1: Questionnaire used in this study

\section{References}

1. Japanese population, Statistic Bureau, Ministry of Internal Affairs and Communications Japan. Available at http://www.stat.go.jp/index.html (2019, May,1, accessed) (In Japanese)

2. Report on Public Health Administration and Services, Overview of employment medical personnel. Ministry of Health, Labor and Welfare Japan Available at https://www.mhlw.go.jp/toukei/saikin/hw/eisei/16/dl/gaikyo.pdf (2019, May,1, accessed) (In Japanese)

3. Vital Statistics. Ministry of Health, Labor and Welfare Japan Available at https://www.mhlw.go.jp/toukei/saikin/hw/jinkou/geppo/nengai17/dl/kekka.pdf (2019, May,1, accessed) (In Japanese)

4. Barnes CM. Dental hygiene intervention to prevent nosocomial pneumonias. J Evid Based Dent Pract. 2014, Suppl:103-114.

5. Yoon MN, Steele CM. Health care professionals' perspectives on oral care for long-term care residents: nursing staff, speechlanguage pathologists and dental hygienists. Gerodontology. 2012; 29: e525-35.

6. Adachi M, Ishihara K, Abe S, Okuda K. Professional oral health care by dental hygienists reduced respiratory infections in elderly persons requiring nursing care. Int J Dent Hyg. 2007; 5:69-74.

7. Adachi M, Ishihara K, Abe S, Okuda K, Ishikawa T. Effect of professional oral health care on the elderly living in nursing homes. Oral Surg Oral Med Oral Pathol Oral Radiol Endod. 2002; 94:191-195.

8. Abe S, Ishihara K, Adachi M, Sasaki H, Tanaka K, Okuda K. Professional oral care reduces influenza infection in elderly. Arch Gerontol Geriatr. 2006; 43:157-164. 
9. Survey of Medical Institutions. Ministry of Health, Labor and Welfare Japan Available at https://www.mhlw.go.jp/toukei/saikin/hw/iryosd/16/dl/02_01.pdf (2019, July,11, accessed) (In Japanese)

10. YoshidaT, EdaS, TakakuS. Study on employee as dental hygienists in dental institutions: SaitamaPref.(in Japanese) Japanese $J$ Dent Prac Adm 2010;44:216-226.

11. Ueda Y, Yagun A, Nagasaki Y, Kago M, Katayama S. Study on the reinstatement of unemployed dental hygienists: Kanagawa Pref. (in Japanese) Japanese. J Dent Prac Adm. 2011; 45:286-293.

12. Usui Y, Miura H. Workforce re-entry for Japanese unemployed dental hygienists. Int J Dent Hyg. 2015; 13:74-78.

13. Survey of working environment of Japanese dental hygienist. Available at https://www.jdha.or.jp/aboutdh/chosa.html\#datakinmu (2019, July,11, accessed) (In Japanese)

14. Abadi N, Mann J, Sela M, Zusman SP. Professional relationship between dentists and dental hygienists in Israel. Isr Dent Hyg Assoc J. 2008; 31: 8-12.

15. Hopcraft M, McNally C, Ng C, Pek L, Pham TA, Phoon WL, et al. Working practices and job satisfaction of Victorian dental hygienists. Aust Dent J. 2008; 53: 61-66.

16. Johnson PM. International profiles of dental hygiene 1987-98: a nineteen-nation comparative study. Int Dent J 2001; 51: 313-324.

17. Johnson PM. International profiles of dental hygiene 1987-2006: a twenty-one-nation comparative study. Int Dent J 2009; 59: 6377.

18. Braunstein N, Mann J, Sela M. Professional relationship between dentists and hygienists in Israel. Adkan 2009; 103: 15-20.

19. Yavnai N, Bilder L, Sgan-Cohen H, Zini A. Dental hygienists in Israel: employment evaluation, job satisfaction, and training implications. J Dent Educ. 2012. 76:1371-1376.

20. Gibbons DE, Corrigan M, Newton JT. A national survey of dental hygienists: working patterns and job satisfaction. Br Dent J. 2001; 190: 207-210.

21. Fung DS, Schwarz E, Tong AC, Wong MC. Dental hygienists in Hong Kong: present and future status. J Dent Hyg. 1996; 70:66-73.

22. Hopcraft M, McNally C, $\mathrm{Ng} \mathrm{C}$ et al. Working practices and job satisfaction of Victorian dental hygienists. Aust Dent J. 2008; 53:6166.

23. Ayers K, Meldrum AM, Thomson WM, Newton JT. The working practices and job satisfaction of dental hygienists in New Zealand. J Public Health Dent. 2006; 66:186-191.

24. Malkawi ZA. Career satisfaction of Jordanian dental hygienists. Int J Dent Hyg. 2016; 14: 243-248.

25. Calley KH, Hodges KO, Johnson R.Prioritization of professional issues by Idaho Dental Hygienists. J Dent Hyg. 2001; 75: $222-231$.

26. Saito A, Tomita C, Sato Y, Cathcart G. Perceptions of Japanese and Canadian dental hygiene students towards their profession. Int J Dent Hyg. 2009; 7: 188-195.

27. Saito A, Sato Y, Nakamura A et al. Development of an International Collaborative Dental Hygiene Programme between Japan and Canada. Int J Dent Hyg. 2008; 6: 328-336.

28. Hillam DG. A survey of hygienists qualifying from the Liverpool School of Dental Hygiene 1977-1998. Br Dent J. 2000; 188:150153.

29. Boyer EM. Job satisfaction among dental hygienists. J Dent Hyg. 1990; 64: 235-238.

30. Schou L, Tronbjerg C, Holst I. A national survey of dental hygienists in Denmark. Community Dent Health. 1986; 3: 91-98.

31. Petrén V1, Levin G, Chohan T et al. Swedish dental hygienists' preferences for workplace improvement and continuing professional development. Int J Dent Hyg. 2005; 3: 117-125.

\section{Tables}

Table 1. Cross tabulation of the items investigated in this study against age groups 
Age group

\begin{tabular}{|c|c|c|c|c|c|c|c|c|}
\hline & & $\begin{array}{l}\leq 29 \\
(n=103)\end{array}$ & $\begin{array}{l}30-39 \\
(n=251)\end{array}$ & $\begin{array}{l}40- \\
49(n=295)\end{array}$ & $\begin{array}{l}50-59 \\
(n=290)\end{array}$ & $\begin{array}{l}60 \leq \\
(n=251)\end{array}$ & $\begin{array}{l}\text { Total } \\
(n=1198)\end{array}$ & $\begin{array}{l}\mathrm{p}- \\
\text { value }\end{array}$ \\
\hline \multicolumn{9}{|l|}{$\begin{array}{l}\text { The reason } \\
\text { of leaving } \\
\text { the job. } \\
\text { (Select } \\
\text { one) }\end{array}$} \\
\hline & $\begin{array}{l}\text { Dissatisfaction } \\
\text { with work } \\
\text { content }\end{array}$ & $5(26.3 \%) \star$ & $5(26.3 \%)^{\star}$ & $5(26.3 \%)$ & $3(15.80 \%)$ & $1(5.30 \%)$ & 19 & $<0.001$ \\
\hline & Payment & $3(7.1 \%)$ & $6(14.3 \%)^{*}$ & $18(42.9 \%)^{*}$ & 14 (33.30\%) & $1(2.40 \%)$ & 42 & \\
\hline & $\begin{array}{l}\text { Trouble in } \\
\text { human } \\
\text { relations in the } \\
\text { workplace }\end{array}$ & $8(28.6 \%)^{\star}$ & $3(10.7 \%)$ & $11(39.3 \%)$ & $4(14.30 \%)$ & $2(7.10 \%)$ & 28 & \\
\hline & Family Matters & $3(2.4 \%)$ & $10(8.1 \%)$ & $52(41.9 \%)$ & $41(33.10 \%)$ & $18(14.50 \%)$ & 124 & \\
\hline & Marriage & $12(25.0 \%)^{\star}$ & $21(43.8 \%)^{*}$ & $9(18.8 \%)$ & $4(8.30 \%)$ & $2(4.20 \%)$ & 48 & \\
\hline & $\begin{array}{l}\text { Childbirth / } \\
\text { child rearing }\end{array}$ & $41(16.7 \%)^{\star}$ & $151(61.6 \%)^{*}$ & $49(20.0 \%)^{*}$ & $3(1.20 \%)$ & $1(0.40 \%)$ & 245 & \\
\hline & $\begin{array}{l}\text { Nursing care } \\
\text { for elderlies of } \\
\text { your family }\end{array}$ & $2(4.1 \%)$ & $1(2.0 \%)$ & $5(10.2 \%)^{*}$ & $28(57.10 \%)$ & $13(26.50 \%)$ & 49 & \\
\hline & $\begin{array}{l}\text { Broke down } \\
\text { my health }\end{array}$ & $4(5.5 \%)$ & $10(13.7 \%)$ & $17(23.3 \%)$ & $25(34.20 \%)$ & 17 (23.30\%) & 73 & \\
\hline & $\begin{array}{l}\text { Interests other } \\
\text { than dental job }\end{array}$ & $10(7.6 \%)$ & $14(10.6 \%)$ & $40(30.3 \%)$ & $51(38.60 \%)$ & $17(12.90 \%)$ & 132 & \\
\hline & Retirement & $0(0 \%)$ & $3(1.8 \%)$ & $3(1.8 \%)$ & $21(12.80 \%)$ & $137(83.50 \%) *$ & 164 & \\
\hline & Others & $12(5.9 \%)$ & $15(7.4 \%)$ & $70(34.3 \%)$ & 79(38.70\%) & $28(13.70 \%)$ & 204 & \\
\hline \multicolumn{9}{|l|}{$\begin{array}{l}\text { Willingness } \\
\text { to reentry. } \\
\text { (Select } \\
\text { one) }\end{array}$} \\
\hline & $\begin{array}{l}\text { As soon as } \\
\text { possible }\end{array}$ & $14(24.1 \%)^{\star}$ & $15(25.9 \%)^{\star}$ & $20(34.5 \%)^{\star}$ & $7(12.10 \%)$ & $2(3.40 \%)$ & 58 & $<0.001$ \\
\hline & $\begin{array}{l}\text { If conditions } \\
\text { are satisfied }\end{array}$ & $62(12.2 \%)^{\star}$ & $177(34.9 \%)^{*}$ & $148(29.2 \%)^{*}$ & $91(17.9 \%)$ & $29(5.70 \%)$ & 507 & \\
\hline & $\begin{array}{l}\text { I do not intend } \\
\text { to }\end{array}$ & $9(2.5 \%) \star$ & $16(4.4 \%)^{\star}$ & $52(14.2 \%)^{\star}$ & $119(32.5 \%)^{\star}$ & $170(46.40 \%)$ & 366 & \\
\hline & Univalent & $16(6.7 \%)$ & $41(17.2 \%)$ & $71(29.8 \%)$ & $70(29.4 \%)$ & $40(16.80 \%)$ & 238 & \\
\hline \multicolumn{9}{|l|}{$\begin{array}{l}\text { How do } \\
\text { you find } \\
\text { your work } \\
\text { for reentry? } \\
\text { (Multiple } \\
\text { choice) }\end{array}$} \\
\hline & $\begin{array}{l}\text { Labor agency } \\
\text { by Ministry } \\
\text { and Labor } \\
\text { welfare }\end{array}$ & $23(5.9 \%)^{*}$ & $58(15.0 \%)^{\star}$ & $104(26.9 \%)^{\star}$ & $105(27.1 \%)^{\star}$ & $97(25.10 \%)$ & 387 & $<0.001$ \\
\hline & $\begin{array}{l}\text { Job } \\
\text { magazines }\end{array}$ & $58(8.6 \%)^{\star}$ & $142(21.0 \%)^{\star}$ & $167(24.7 \%)^{\star}$ & $176(26.0 \%)^{\star}$ & $134(19.80 \%)$ & 677 & $<0.001$ \\
\hline & Friend & $50(9.6 \%)$ & 127(24.4\%) & $132(25.3 \%)$ & 132(25.3\%) & $80(15.40 \%)$ & 521 & 0.785 \\
\hline \multicolumn{9}{|c|}{ Page $8 / 12$} \\
\hline
\end{tabular}




\begin{tabular}{|c|c|c|c|c|c|c|c|c|}
\hline & $\begin{array}{l}\text { Dental } \\
\text { hygienist } \\
\text { school }\end{array}$ & $76(8.1 \%)^{\star}$ & $210(22.4 \%)^{\star}$ & $253(27.0 \%)^{\star}$ & $241(25.7 \%)^{\star}$ & 158(16.80\%) & 938 & $<0.001$ \\
\hline & Internet & $73(8.8 \%)^{\star}$ & 164(19.7\%)* & $219(26.3 \%)^{\star}$ & $218(26.2 \%)^{\star}$ & 158(19.00\%) & 832 & $<0.001$ \\
\hline & $\begin{array}{l}\text { Dental } \\
\text { Association / } \\
\text { Dental } \\
\text { Hygienist } \\
\text { Association }\end{array}$ & $72(9.8 \%)$ & $176(24.0 \%)$ & $180(24.5 \%)$ & $190(25.9 \%)$ & $116(15.80 \%)$ & 734 & 0.121 \\
\hline & $\begin{array}{l}\text { Human } \\
\text { resource } \\
\text { dispatch } \\
\text { company }\end{array}$ & $96(9.4 \%)$ & $239(23.5 \%)$ & $269(26.4 \%)$ & $251(24.6 \%)$ & 164(16.10\%) & 1019 & 0.573 \\
\hline & Other & $92(9.2 \%)$ & $240(24.0 \%)$ & $274(27.4 \%)$ & $242(24.2 \%)$ & $152(15.20 \%)$ & 1000 & 0.025 \\
\hline \multicolumn{9}{|l|}{$\begin{array}{l}\text { Is there any } \\
\text { obstacle } \\
\text { for the } \\
\text { reentry? } \\
\text { (Yes or No) }\end{array}$} \\
\hline & Yes & $84(9.4 \%)$ & $212(23.6 \%)^{\star}$ & $240(26.7 \%)^{\star}$ & $221(24.6 \%)$ & $141(15.7 \%)$ & 898 & 0.064 \\
\hline \multicolumn{9}{|l|}{$\begin{array}{l}\text { What is } \\
\text { your } \\
\text { obstacle } \\
\text { for reentry? } \\
\text { (Multiple } \\
\text { choice) }\end{array}$} \\
\hline & Salary & $60(8.6 \%)^{\star}$ & $144(20.6 \%)^{\star}$ & $169(24.1 \%)^{*}$ & $189(27.0 \%)^{*}$ & 138(19.70\%) & 700 & $<0.001$ \\
\hline & Working hours & $33(8.1 \%)^{\star}$ & $44(10.8 \%)^{*}$ & $91(22.3 \%)^{\star}$ & $\begin{array}{l}126 \\
(30.9 \%)^{*}\end{array}$ & $114(27.90 \%)$ & 408 & $<0.001$ \\
\hline & My skills & $33(7.4 \%)^{*}$ & $126(28.3 \%)$ & $97(21.7 \%)^{*}$ & $99(22.2 \%)^{*}$ & $91(20.40 \%)$ & 446 & $<0.001$ \\
\hline & $\begin{array}{l}\text { No } \\
\text { consultation }\end{array}$ & $79(9.2 \%)$ & $202(23.5 \%)$ & $233(27.1 \%)$ & $212(24.6 \%)$ & $135(15.70 \%)$ & 861 & 0.822 \\
\hline & Aged & $77(12.9 \%)$ & 202(33.9\%) & 191(32.0\%) & 106(17.8\%) & $20(3.40 \%)^{*}$ & 596 & $<0.001$ \\
\hline & Others & $69(9.4 \%)$ & $171(23.4 \%)$ & 195(26.7\%) & $181(24.8 \%)$ & $115(15.70 \%)$ & 731 & 0.995 \\
\hline \multicolumn{9}{|l|}{$\begin{array}{l}\text { What kind } \\
\text { of lecture } \\
\text { course } \\
\text { contents } \\
\text { do you } \\
\text { want to } \\
\text { attend for } \\
\text { reentry? }\end{array}$} \\
\hline & $\begin{array}{l}\text { Scaling and } \\
\text { route planning }\end{array}$ & $19(6.0 \%)^{\star}$ & $54(17.1 \%)^{\star}$ & $90(28.6 \%)^{*}$ & $93(29.5 \%)$ & $59(18.70 \%)$ & 315 & $<0.001$ \\
\hline & $\begin{array}{l}\text { Dental caries } \\
\text { prevention and } \\
\text { control }\end{array}$ & $32(6.7 \%)^{*}$ & $119(24.9 \%)$ & $142(29.8 \%)$ & $120(25.2 \%)$ & $64(13.40 \%)$ & 477 & 0.001 \\
\hline & $\begin{array}{l}\text { Individual } \\
\text { instruction of } \\
\text { dental health }\end{array}$ & $34(8.1 \%)$ & $107(25.4 \%)$ & $133(31.5 \%)$ & $100(23.7 \%)$ & $48(11.40 \%)$ & 422 & 0.297 \\
\hline & $\begin{array}{l}\text { Group } \\
\text { instruction of } \\
\text { dental health }\end{array}$ & $51(10.3 \%)^{*}$ & $132(26.7 \%)$ & $139(28.1 \%)$ & $120(24.2 \%)^{*}$ & $53(10.70 \%)$ & 495 & 0.079 \\
\hline & $\begin{array}{l}\text { Handling of } \\
\text { dental } \\
\text { materials, }\end{array}$ & $40(8.5 \%)^{\star}$ & $\begin{array}{l}113 \\
(24.1 \%)^{*}\end{array}$ & $129(27.6 \%)^{*}$ & $122(26.1 \%)$ & $64(13.70 \%)$ & 468 & 0.004 \\
\hline
\end{tabular}




\begin{tabular}{|c|c|c|c|c|c|c|c|}
\hline $\begin{array}{l}\text { Chair side } \\
\text { assistant snap } \\
\text { impression, } \\
\text { polishing of } \\
\text { filling } \\
\text { materials, } \\
\text { rubber dam } \\
\text { etc. }\end{array}$ & $35(7.3 \%)^{\star}$ & $107(22.3 \%) *$ & $136(28.4 \%) *$ & $132(27.6 \%)$ & $69(14.40 \%)$ & 479 & $<0.001$ \\
\hline Nursing care & $48(11.0 \%)^{\star}$ & $122(27.9 \%)$ & $124(28.3 \%)$ & $94(21.5 \%)$ & $50(11.40 \%)$ & 438 & 0.130 \\
\hline $\begin{array}{l}\text { Swallowing } \\
\text { function } \\
\text { training, }\end{array}$ & $38(13.6 \%)^{*}$ & $95(34.1 \%) *$ & $69(24.7 \%)$ & $52(18.6 \%)$ & $25(9.00 \%)$ & 279 & $<0.001$ \\
\hline $\begin{array}{l}\text { Muscle } \\
\text { function } \\
\text { training, }\end{array}$ & $48(13.0 \%)^{*}$ & $112(30.4 \%) *$ & $101(27.4 \%)$ & $76(20.6 \%)$ & $32(8.70 \%)$ & 369 & $<0.001$ \\
\hline Counseling & $40(9.2 \%)$ & $120(27.7 \%)$ & $119(27.5 \%)$ & $100(23.1 \%)$ & $54(12.50 \%)$ & 433 & 0.697 \\
\hline $\begin{array}{l}\text { Professional } \\
\text { oral care } \\
\text { techniques, }\end{array}$ & $37(12.5 \%) *$ & $85(28.8 \%)$ & $77(26.1 \%)$ & $62(21.0 \%)$ & $34(11.50 \%)$ & 295 & 0.036 \\
\hline Others & $57(9.1 \%)$ & $164(26.2 \%)$ & $182(29.1 \%)$ & $145(23.2 \%)$ & $78(12.50 \%)$ & 626 & 0.783 \\
\hline
\end{tabular}

8 Subjects with No answer for the age groups were excluded from the Table.

*indicated the statistically significant cells by logit model of log-linear analysis.

Table 2. Characteristics of the subjects participated in this study by classification of willingness to reentry 


\begin{tabular}{|c|c|c|c|c|c|c|}
\hline & \multicolumn{3}{|l|}{$\begin{array}{l}\text { Willingness to } \\
\text { reentry }\end{array}$} & \multirow{3}{*}{$\begin{array}{l}\text { Univalent } \\
(n=239)\end{array}$} & \multirow{3}{*}{ Total } & \multirow{3}{*}{$\begin{array}{l}\mathrm{p}- \\
\text { value }\end{array}$} \\
\hline & & & & & & \\
\hline & $(n=59)$ & $(n=510)$ & $(n=369)$ & & & \\
\hline Age & $38.2 \pm 11.1 \S \S, \S \S \S$ & $41.5 \pm 10.5 \zeta, \zeta \zeta$ & $\begin{array}{l}57.4 \pm 10.9 \\
\zeta \zeta \zeta\end{array}$ & $47.8 \pm 11.2$ & $47.6 \pm 12.9$ & $<0.001$ \\
\hline $\begin{array}{l}\text { Year of working as dental } \\
\text { hygienist }\end{array}$ & $11.3 \pm 10.0 \S \S$ & $12.6 \pm 8.6 \zeta$ & $22.0 \pm 13.2 \zeta \zeta \zeta$ & $14.5 \pm 10.4$ & $15.9 \pm 11.4$ & $<0.001$ \\
\hline Year since leaving job & $4.2 \pm 7.2 \S \S, \S \S \S$ & $5.3 \pm 6.6 \zeta, \zeta \zeta$ & $\begin{array}{l}11.5 \\
\pm 10.3 \zeta \zeta \zeta\end{array}$ & $9.2 \pm 9.1$ & $8.0 \pm 8.9$ & $<0.001$ \\
\hline \multicolumn{7}{|l|}{$\begin{array}{l}\text { The reason of leaving the job. } \\
\text { Select one }\end{array}$} \\
\hline $\begin{array}{l}\text { Dissatisfaction with work } \\
\text { content }\end{array}$ & $1(5.0 \%)$ & $5(25.0 \%)$ & $7(35.0 \%)$ & $7(35.0 \%)$ & 20 & $<0.001$ \\
\hline Payment & $0(0 \%)$ & $24(57.1 \%)^{*}$ & $11(26.2 \%)$ & $7(16.7 \%)$ & 42 & \\
\hline $\begin{array}{l}\text { Trouble in human relations in } \\
\text { the workplace }\end{array}$ & $5(17.9 \%)$ & $12(42.9 \%)$ & $5(17.9 \%)$ & $6(21.4 \%)$ & 28 & \\
\hline Family Matters & $3(2.4 \%)$ & $60(48.0 \%)$ & $38(30.4 \%)$ & $24(19.2 \%)$ & 125 & \\
\hline Marriage & $2(4.2 \%)$ & $21(43.8 \%)$ & $12(25.0 \%)$ & $13(27.1 \%)$ & 48 & \\
\hline Childbirth / child rearing & $23(9.4 \%)^{\star}$ & $189(77.5 \%)^{\star}$ & $\star 7(2.9 \%)$ & $25(10.2 \%)$ & 244 & \\
\hline $\begin{array}{l}\text { Nursing care for elderlies of your } \\
\text { family }\end{array}$ & $0(0 \%)$ & $18(37.5 \%)$ & 16(33.3\%) & $14(29.2 \%)$ & 48 & \\
\hline Broke down my health & $1(1.4 \%)$ & $34(45.9 \%)$ & $21(28.4 \%)$ & $18(24.3 \%)$ & 74 & \\
\hline Interests other than dental job & $1(0.8 \%)^{\star}$ & $36(27.5 \%)$ & $\star 59(45.0 \%)$ & $35(26.7 \%)$ & 131 & \\
\hline Retirement & $5(3.1 \%)$ & $24(14.7 \%)$ & $114(69.9 \%)$ & $20(12.3 \%)$ & 163 & \\
\hline Others & $16(8.0 \%)$ & 61(30.3\%) & 68(33.8\%) & $56(27.9 \%)$ & 201 & \\
\hline \multicolumn{7}{|l|}{$\begin{array}{l}\text { Is there any obstacle for the } \\
\text { reentry? }\end{array}$} \\
\hline Yes & $13(6.5 \%)$ & $62(31.0 \%)^{\star}$ & $80(40.0 \%)^{\star}$ & $45(22.5 \%)$ & 200 & $<0.001$ \\
\hline \multicolumn{7}{|l|}{$\begin{array}{l}\text { What is your obstacle for } \\
\text { reentry? }\end{array}$} \\
\hline Salary & $4(2.1 \%)^{\star}$ & $115(59.6 \%)$ & $33(17.1 \%)$ & $41(21.2 \%)$ & 193 & 0.002 \\
\hline Working hours & $28(5.7 \%)^{\star}$ & $319(65.1 \%)^{\star}$ & $55(11.2 \%)^{\star}$ & $88(18.0 \%)$ & 490 & $<0.001$ \\
\hline My skills & $17(3.8 \%)^{\star}$ & $208(46.0 \%)^{\star}$ & $110(24.3 \%)^{\star}$ & $117(25.9 \%)$ & 452 & 0.004 \\
\hline No consultation & $1(3.0 \%)$ & $23(69.7 \%)$ & $1(3.0 \%)^{\star}$ & $8(24.2 \%)$ & 33 & 0.023 \\
\hline Aging & $7(2.4 \%)$ & $91(30.7 \%)$ & $121(40.9 \%)$ & $77(26.0 \%)^{*}$ & 296 & $<0.001$ \\
\hline Others & $16(9.8 \%)$ & $76(46.3 \%)$ & $38(23.2 \%)$ & $34(20.7 \%)$ & 164 & 0.023 \\
\hline
\end{tabular}

21 Subjects with No answer for Willingness to reentry were excluded from the Table.

Statistically significant difference between

§: As soon as possible and If conditions are satisfied, §§: As soon as possible and I do not intend to

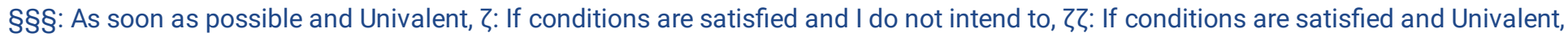
$\zeta \zeta \zeta:$ I do not intend to and Univalent, respectively. 


\section{Figures}

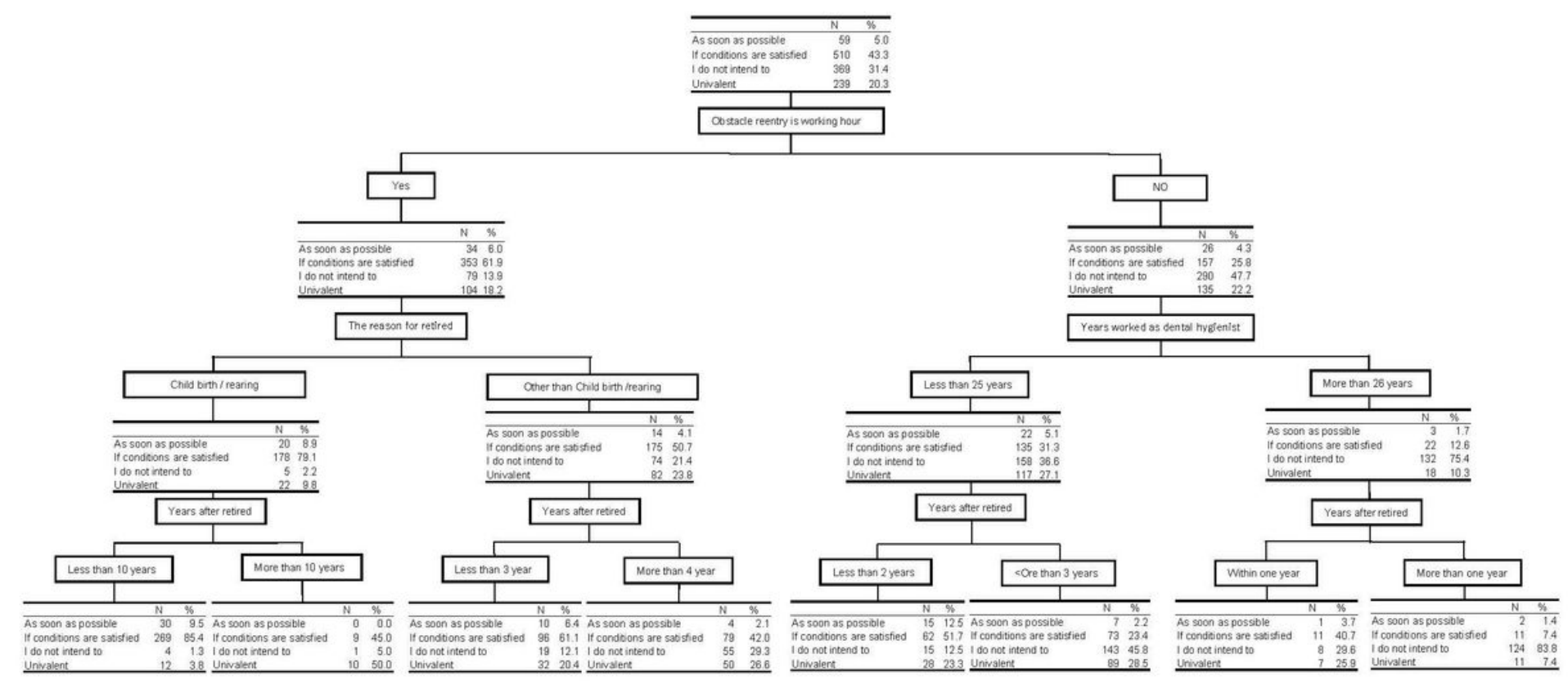

\section{Figure 1}

Decision analysis for the willing ness of reentry of the dental hygienist jobs Working hours was the most important determinant of the willingness of reentry. Among the 59 dental hygienist who willing to reentry for the jobs as soon as possible, 30 subjects had following conditions: obstacle for reentry was working hours, the reason of retired as child birth/ rearing, and less than 2 years after retired.

\section{Supplementary Files}

This is a list of supplementary files associated with this preprint. Click to download.

- Additionalfile1.docx 